\title{
'Lovers of Beauty': The Oeuvres of George Santayana, Fred Holland Day and Edward Perry Warren as Exemplifications of Aesthetics of Existence Influenced by the Platonic Eros
}

\begin{abstract}
My theory is about the lovers of beauty who tried to aestheticize their existences in different ways, but with the same goal: to make life into an oeuvre. George Santayana created an aesthetic ontology, Fred Holland Day made a photo composition (Beauty is Truth), which is the essence of his aesthetics of existence, and Edward Perry Warren spiritualized the male ideal shaped through the praising of the Uranian Eros. They used the Hellenic idea as a life-giving energy, they re-eroticised the philosophical thoughts about self-creation and the aesthetic way of life. The serious questions of private perfection and self-creation can be the basis of an ethics of personality. According to Agnes Heller it is always the ethics of one person. We have to illustrate it, if we want to speak about it. So, we have to examine one paradigmatic case to illustrate the essence of it.
\end{abstract}

\section{Key words}

Eros; philosophers of the art of living; George Santayana; Fred Holland Day; Edward Perry Warren

"The world, however callous, is not yet dead to the ideal."

(Edward Perry Warren)

"when he sees the beauty of earth, is transported with the recollection of the true beauty; he would like to fly away, but he cannot; he is like a bird fluttering and looking upward and careless of the world below; and he is therefore thought to be mad. And I have shown this of all inspirations to be the noblest and highest and the offspring of the highest to him who has or shares in it, and that he who loves the beautiful is called a lover because he partakes of it." 
In 1904 an antique statue was found in the Mediterranean Sea. It became very famous, as The Winged Eros of Tunis. George Edward Woodberry wrote a poem about its beauty and emphasized that "no Christian touch profaned" its inviolate form and that "The beautiful boy, reborn/ Of the waves for our worship and love" (1914b: 29-30). The cult of Eros was a living presence for the Victorian intellectuals. We can find the causes for this in the educational system and in their huge respect toward the classics.

Plato's Symposium and Phaedrus are the most important European philosophical texts about the power of Eros, about male love, about the higher forms of knowledge and beauty. Through these works aesthetic and sexual discourses emerged and are connected. According to Plato the lover of beauty can remember the absolute beauty: "who has been the spectator of many glories in the other world, is amazed when he sees any one having a godlike face or form, which is the expression of divine beauty" (251a). Eros is the desire of "the everlasting possession of the good", "the love of generation and of birth in beauty", thus the desire of immortality (Symposium: 206 a-e). In the Symposium there is one of the most influential theses of Plato about rising from the carnal and fleshly temptations to the heavenly sphere, to the divine. At the top of Plato's imaginary ladder, that men have to mount in order to purify themselves, there is immortality and the revealed vision of absolute beauty, but Platonic Eros is not a synonym for the ethereally clean spiritual longing without erotic features. As Gregory Vlastos declared: "'Platonic love', is a peculiar mix of sensuality, sentiment, and intellect - a companionship bonded by erotic attraction no less than by intellectual giveand-take" (1973: 40).

Michel Foucault in his History of Sexuality put "genealogy of desiring man" in the center and placed techniques of the self, self-creation and arts of existence into the first line of philosophical debates. Foucault and his contemporary, Pierre Hadot's works affected Alexander Nehamas' and Richard Shusterman's thoughts on the aesthetics of existence. Foucault is a turning point, the man who opened the door to the subject matter of therapy of desire. In the last thirty years, philosophical publications on the aesthetic way of life have insisted that Foucault gave one of the most important analyses of the connection between ancient Greek philosophy and lifestyle. Hadot highlighted (1995) that we have to esteem Plato's works as "thought-practices" and spiritual exercises. Alexander Nehamas in The Art of Living, Socratic Reflections from Plato to Foucault consistently applied the term "philosophers of the art of living". I agree with Nehamas's suggestion that there is no one definitely acceptable lifestyle which can be convenient for everyone, and philosophical life can be only one possible way among others, but it must be admitted that a philosophical conception which is indeed the art of life does exist (Nehamas 1998: 2-3). Richard Shusterman writes: "As concretely embodied practice rather than formulated doctrine, how is philosophy to be taught and learned? [...] The only obvious answer is the emulation of distinguished exemplars" but later he added, that it was obviously not the particular person but the philosophical life-practice which was exemplary (1997: 18). The philosophers of 
the art of living - says Nehamas, sometimes play a double role: "they are both the characters their writings generate and the authors of the writings in which their characters exist. They are creators and creatures in one" (1998: 2-3). More importantly, that

the philosophers of the art of living make the articulation of a mode of life their central topic: it is by reflecting on the problems of constructing a philosophical life that they construct the life their work constitutes. The body of work that reflects on the philosophical life is the very content of the life it composes. (Nehamas 1998: 6)

The serious questions of private perfection and self-creation can be the basis of an ethics of personality. In Nietzsche's view the greatest examples of the ethics of personality fascinate with his or her existence. According to Agnes Heller the ethics of personality is always the ethics of one person. It is impossible to write a treatise about ethics of personality, in general. We have to illustrate it, if we want to speak about it. So, we have to examine one paradigmatic case, one person, one life, to illustrate its essence (Heller 1994: 7). I believe that we cannot ignore the work's creator when we postulate a personal life-philosophy composed into an oeuvre. Biographical features are essential elements of life-experience, which is a pawn of authenticity, but ideas have to be placed to the achronism of works of art. Writings, pictures, and statues are equally able to show up ideas, so I think we have to amplify the considerations focused on writings, and we have to examine the possibilities of ideas' appearances in different creations. According to Nietzsche's famous remark in his Ecce Homo, an idea is the mirror of its creator, which helps the process when one becomes what one is (Nietzsche 1911: 9).

My theory is about modern lovers of beauty, who tried to aestheticize their existences in different ways, but with the same goal: to make life into an oeuvre. They determined the aesthetic thought and artistic life of the USA from the end of the nineteenth century. Aesthetics was a neglected area of American philosophy that time. In 1879 G. Stanley Hall remarked that it was not surprising without museums, galleries, or even photographs (1879: 95). With the generation of Santayana, Fred Holland Day and Edward Perry Warren everything has changed.

My aim is not to judge who is a philosopher and who is not. The question is, who can show up a complete and significant creation full of special meanings built up from the ancient philosophical tradition. The main feature in Santayana's, Day's and Warren's personality is desiring, after something had disappeared hundreds of years ago, and after the Platonic admiration toward beauty. This desiring has an overt erotic trait, and its history of reception is full of obfuscations. Santayana, Day and Warren knew the enticing power of obfuscations well. Their lives and works are determined by sensual impulses derived from Plato's works. Warren and his friends' thoughts and attractions were justified and legitimated by Plato and the aestheticist interpretators of Plato (John Addington Symonds, Walter Pater etc.). They all identified themselves with the few described by 
Plato in Phaedrus, who are guileless lovers of philosophy or philosophical lovers of boys (249a). These intellectuals found an idea inspired by the Platonic Eros, idealized by Greek mythology, religion, philosophy, masculine hero-cult, greek love- and friendship ideals, which are equally important in it with the cardinal role of beauty's power. Socrate's sentences in Plato's Symposium and Phaedrus made the 'lovers of boys' proud. Antique examples changed the followers' lives and drove them as lanterns in a different time and culture. Hellenic idea became a life-giving energy in the circle of aesthetic Platonists.

"The ideal artist, like the ideal philosopher, has all time and all existence for his virtual theme. Fed by the world he can help to mould it, and his insight is a kind of wisdom ..."

(George Santayana)

George Santayana was a Spanish-born American philosopher and poet, a Harvardian professor, medieval vagan and hermit in his later life. In one of his confessions Santayana declares that the subject-matter of his work might be divided into two strands, the poetic and the academic. He makes a clear distinction between these categories:

My verses and my private philosophizing belonged to me, expressed me, and were addressed essentially to nobody else; the academic subjects were suggested or imposed by circumstances, and I appear there in the costume and under the mask of an assumed character. (Santayana 1957: 5)

"Private philosophizing" is a very attractive term that Santayana coined but we cannot figure out which books belong to this category. He thought that philosophical contemplation is a literary activity. In a preface he writes about his verses:

For as to the subject of these poems, it is simply my philosophy in the making. [...] I see no reason why a philosopher should be puzzled. What he sees he sees; of the rest he is ignorant; and his sense of this vast ignorance (which is his natural and inevitable condition) is a chief part of his knowledge and of his emotion. Philosophy is not an optional theme that may occupy him on occasion. It is his only possible life, his daily response to everything. [...] Everything he thinks or utters will accordingly be an integral part of his philosophy, whether it be called poetry or science or criticism.

(Santayana 1922: xii-xiii)

Obviously, philosophizing is a lifestyle for Santayana and it is impossible to separate his writings in the way as he thought sometimes. Masks cannot hide his real profile anymore, knowing his emotions and motivations from his verses. When 
he set his Apologia down, Santayana felt that his aestheticism was "a modest Epicurean humanism" (Santayana 1940: 503). He called his philosophy a "lay religion" based on the disciplining of the mind and the heart. Santayana's crutches in reaching complete life are poetry for him, equivalent to religion, art and aspiration toward perfection. In the latter, love and friendship are one and the same from the point of view of desire. In the dictionary of Santayana, perfection and beauty are not separable ideas, whereas beauty is the objectified pleasure, the feeling of pleasure will give the feeling of perfection. In the Sense of Beauty he declares:

That man is unhappy indeed, who in all his life has had no glimpse of perfection, who in the ecstasy of love, or in the delight of contemplation, has never been able to say: It is attained. Such moments of inspiration are the source of the arts, which have no higher function than to renew them. A work of art is indeed a monument to such a moment, the memorial to such a vision. (Santayana 1955: 160)

Love, as the indispensable component of a good life, is a returning subject in the works of Santayana. His early sonnets feed on the idea of immortal love, he built up the last chapters of The Sense of Beauty to the psychology of desire, and he dedicated a chapter to love in Reason in Society. In The Interpretations of Poetry and Religion and in Three Philosophical Poets, the triplicity of love, desire and sexuality play a crucial role in revealing the nature of the relationship between poetry and philosophy. In the introduction of the essay titled Love, Santayana calls our attention to the fact that two things need to be admitted if we speculate about love: "one, that love has an animal basis; the other, that it has an ideal object" (1930: 8). Love without imagination and idealization is inconceivable for Santayana. In his essay about Platonic Love Santayana declares that Platonic love was the essence of Platonic philosophy. He gives an amazing analysis of love and beauty:

There is, at any rate, no sphere in which the supersensible is approached with so warm a feeling of its reality, in which the phenomenon is so transparent and so indifferent a symbol of something perfect and divine beyond. In love and beauty, if anywhere, even the common man thinks he has visitations from a better world, approaches to a lost happiness; a happiness never tasted by us in this world, and yet so natural, so expected, that we look for it at every turn of a corner, in every new face; we look for it with so much confidence, with so much depth of expectation, that we never quite overcome our disappointment that it is not found. And it is not found, no, never, in spite of what we may think when we are first in love. (Santayana 1931: 100-101)

In Santayana's conception of love, Eros is the driving power toward perfection and Eros means a huge desire: "So that if there is anything morbid in Platonic love, it is not its unnatural coldness, but its disproportionate fervor, not the barren egoism of it, but its suicidal self-surrender" (1913: 595). Santayana always dealt 
with this special mode of love which is full of grief and loss. He pronounced in an essay that "all mortal loves are tragic because never is the creature we think we possess the true and final object of our love" (1927: 141). There are similar feelings in his sixteenth (XVI.) sonnet: "I knew/ The wings of sacred Eros as he flew/ And left me to the love of things not seen./ IT is a sad love, like an eternal prayer,/ And knows no keen delight, no faint surcease." He thought that perfect love was founded on despair (Santayana (1896: 18, 37). We can find the explanation in his autobiography: "It is not love simply, but only perfect love that includes despair. Love in itself includes hope, or at least a desire to preserve the object of it, to enshrine and defend it. [...] The perfect lover must renounce pursuit and the hope of possession" (Santayana 1953: 14).

Santayana's personal relations are not completely known, but we can understand many things from his verses. According to his biographers Santayana as a young man loved one of his friends with all his heart. He was Warwick Potter, the addressee of four sonnets. After Potter's early death Santayana broke down. The boy's figure remained an eternal model for him. Gradually Potter transformed in his verses into a virginal, spiritual beauty. Time left untouched his beauty and goodness. Potter became an eternal erotic figure to whom Santayana could always remain faithful (Martin 1998: 110). Santayana called this sad period of his life, his philosophical metanoia and says: "The platonic transition was therefore at once spontaneous and inevitable, from the many to the one, from the existent but transitory to the ideal and eternal" (1953: 8). Santayana is not a pure Platonist nor a pure naturalist, he did not believe in independent ideas. In his youth Santayana felt very close to Plato and Schopenhauer and wanted to write his dissertation on the latter. When his plan failed, he created The Sense of Beauty. Whitney Davis alleges that

nineteenth-century theorists of the arts recognized that Schopenhauer offered a middle way between strict Platonic idealism, which typically criticized the sensuous partiality and conceptual parochialism of artistic representations, and Paterian sensationalism, which privileged sensory appreciation of their finest textures. (Davis $2010: 84$ )

I need to question Davis's view over one detail. In my opinion in the Platonic dialogues Socrates does not represent consistently the "strict idealism". He admired the perfectly shaped bodily forms because of their divine natures. The appreciation of perfect forms is a privilege of Plato and the man who has sensibility to it is erotic and close to the divine. The special, refined perception can stir men's feelings. Perhaps they do nothing, as Socrates next to Alcibiades in the Symposium, but feel and portray the disturbing experience. Speaking about the power of Eros, about the energy which makes men self-sacrificing is meaningless without assuming real desires. Alcibiades's upset insists that Socrates's attitude is rare and special. As he says at the end of Symposium: 
he was so superior to my solicitations, so contemptuous and derisive and disdainful of my beauty - which really, as I fancied, had some attractions - hear, O judges; for judges you shall be of the haughty virtue of Socrates nothing more happened, but in the morning when I awoke (let all the gods and goddesses be my witnesses) I arose as from the couch of a father or an elder brother. (219d)

Manners were different in every city-state, and the philosophically understandable subtleties were not easily apparent in everyday life, but a certain honour toward virtuous men is obvious in the platonic dialogues. Artists, writers and philosophers have the opportunity to create something - an idea, a novel, a verse, or any kind of works of art, but the perfectly shaped wholenesses do not need to show up the pure reality. They are ideals for the creators and enigmas for the interpretators. As Foucault observed:

It is one's own soul that must be constituted in what one writes; but, just as a man bears his natural resemblance to his ancestors on his face, so it is good that one can perceive the filiation of thoughts that are engraved in his soul. Through the interplay of selected readings and assimilative writing, one should be able to form an identity through which a whole spiritual genealogy can be read. (Foucault 1983)

Observing Santayana's early vital philosophy we can predict an ethics of personality. His aesthetic ontology contains the milestones of a self-created life. His writings about searching for beauty are not isolated theoretical works, but poetically composed self-expressions, elements of his self-training.

\section{II}

"I like to think of my life as a fight for friendship, against modern ideas

- my protests are the collection of Greek antiquities and my writings, and against domesticity when it tends to be hostile. [...] my verses and my prose advocate a morality, but it is not the current morality in certain matters.

$[\ldots]$ It is not important to write much; it is important to leave pages which can be believed as a record of life. How could I write them if faithless?"

(Edward Perry Warren)

Edward Perry Warren is one of the most important personalities in the history of American archeology and museology, but whose literary and philosophical lifework is completely and deliberately forgotten. In all of his life he followed one idea, his artistic, poetical and philosophical activities show the same intention. The same passion sustained his works and life. He left behind something whole, that is really a precious record of his life and of an idea. He truly honoured the Greek or Hellenist idea as he called it, and created a new theory of virtue. This 
theory became the essence of his oeuvre, he immortalized the most important thesis of his personal philosophy in it. Theory was not enough for him, he always tried to demonstrate the practicability of his thoughts. We can read in Burdett and Goddard that "the real scholar, however had no narrow, still less a bookish idea of 'theoria'. The theory was studied for the safeguard of practice, the reflection of life..." (Burdett and Goddard 1941: 92; 2013/I: 102). Warren wrote in 1889 in a letter to John Marshall: "Plato has given me help and confirmed some of my ideas, but I must use his evidence indirectly and not pose as a Greek astray, although I feel my separation from modern life often..." (Burdett and Goddard 1941: 116; 2013/I: 129). Warren's own ideas about the ideal was always in his mind. In 1901, he wrote to his lover:

I don't think you are like myself. The person for you is everything. I want my friend but I leave him behind, I do not live only for a friend. But I am to live for something, for the idea; and I cannot pursue it without some spiritual atmosphere. (Burdett and Goddard 1941: 394; 2013/I: 423-424)

He wanted to give his message to his followers, the noble, masculine and aristocratic theory of friendship and what is connected to it. His Magnum Opus, the three volumed A Defence of Uranian Love is the synthesis of the oneness of his work and life. We can declare that the process of the writing and the created work is the interpretative reliving of his life and thoughts. Its biggest value is authenticity, which is the most important feature in a personal ethics. There is a very interesting line in his verse titled New and Old: "I singing of the past, redeem the past from death. If Fate have granted me to live, more than the past is mine to give..." (Warren 2013/II.: 96). The significance of these lines for me is that he searched for thoughts from Antiquity, for Greek hero- and friendship-cult, he tried to preserve the old statues and stones but more importantly, he wanted to revive the virtues of his heroes - of Achilles and Patroclus, and the heroes of Pindar. It was quite an impossible venture, and took a real courage in the 1920s in England, where nobody knew correctly what was the difference between pederasty, uranism, and homosexuality, but laws punished everything. It is obvious, that Warren was pregnant in his soul - in a Platonic way. As Plato writes in the Symposium:

And he who in youth has the seed of these implanted in him and is himself inspired, when he comes to maturity desires to beget and generate. [...] when he finds a fair and noble and well-nurtured soul, he embraces the two in one person, and to such an one he is full of speech about virtue and the nature and pursuits of a good man; and he tries to educate him. (209 b-d)

To Warren, education seemed the most efficient device to revive the theory. Education in a school, at a brotherhood or personally, through love. The Defence is the record of the latter. Warren created his alter ego, and outlined his personal development. In one case he displayed the shaping of the disciplined, masculine and 
honest lover. Firstly we know a young beloved and later the lover. The Magnum Opus is the praising of the masculine:

both lover and beloved are to be directly in relation with their proper ideal, the masculine. This seems to be the peculiar advantage of such love, the advantage which renders it indeed a philosophical passion." [The lover] "and his beloved are in training al $\sigma \kappa \eta \sigma 1 \varsigma$, but it is not the Christian 'ascetic' mortification (Warren 1928: 79; 2013/II: 395).

The enthusiastic love of the masculine has its roots in Plato too. According to the Symposium the souls derived from the heavenly Eros "turn to the male, and delight in him who is the more valiant and intelligent nature" (181c). Burdett \& Goddard described perfectly Warren's method: "the argument quickly develops into a 'philosophic passion" and "this argument is that it is only Love, and consequently only a theory of Love, that makes life worth living" (1941:301; 2013/I: 331-332). Plato wrote the same about Eros. Eros is the one and only who was able to induce great thoughts and strong friendships among men. These thoughts are formulated in Symposium, in the speech of Pausanias. Every sign points to the fact that this part of Plato's work was more important to Warren than the others. In 1887 he wrote an interesting and sensitively created story titled A Tale of Pausanian Love. It is about three boys, who lived and studied at Oxford. Warren placed his memories and experiences to this "tale" and composed his feelings into a love story. This writing is not only a short novel but searching for answers about the real meaning of Plato's words, and it is about the development of a young soul, who tried to find his way in life. One of the characters is Alfred Byngham who said that: "The Symposium was once my charter" (Warren 2013: 485). Claud Sinclair, his devoted friend could not understand immediately Byngham's words but he remembered the boy's earlier opinion of Plato: "You told me once he gave you yourself" - he said and remarked that he was always curious to know how, and never dared to ask (Warren 2013: 485). The Uranian doctrine is attached to the masculine and itself "the idea and form of virtue" (Warren 1930: 20; 2013/II: 460). When Warren's hero in the Defence became the servant and defender of the masculine, "henceforth there was something more in the world than self-restraint; there was self" (Warren 1928: 42; 2013/II: 371). Perhaps not well, but I appreciate this point as the highlight of the character's evolution. I think it is the same when someone declares that he becomes what he is. Philosophically this stage has the biggest significance. In the Tale of Pausanian Love Warren formulated one of his doubts:

Was the love of the male, then only a training at best, a training to come to an end with the full development of the beloved? or could it reach its climax in the love of men?

I told him it could - I thought it probably had, even in Greek times.

(Warren 2013: 522) 
If we want to fully understand the features of different loves, or the different sides of Eros we have to read the second part of the Defence. There is a precise explanation: "The paederastic Eros is the love of youth, the philosphic Eros the love of philosophy. The Uranian Eros is less sensual than the first and less abstract than the second: it is the love of the very root and fibre of manhood..." (Warren 1930: 164; 2013/II: 559). The last lines of the second volume are as follows: "The paederastic Eros lost itself in the Uranian Eros, of which it held its life and its licence to live, as the Uranian love lost itself in that which is more than love, the worship of Zeus" (Warren 1930: 166; 2013/II: 560). We do not receive more information about why this worship is so important. Perhaps we can find Warren's purpose with the help of Plato's Phaedrus. Plato writes that every soul rambles around the Gods before people come into the world. The souls wander around Zeus later on imitate Zeus and try to find zeusian friends. If they find the perfect partner they want to make him totally akin to Zeus. They shape their lovers and honor them as statues of Zeus. Boys win the right to praise. So, a boy with the best qualities is able to become a statue of god with the help of a lover. The Greek statues express ideas. This is the main element of the Uranists' enthusiasm toward Greek statues. In the worship of the statues they can live the celebration of the idea. According to Burdett \& Goddard:

Warren was one of the few to whom beauty was a passion, who believed almost fanatically in the necessity of beautiful things for the salvation of the soul. When he presented to the Ashmolean a splendid bronze head, or some vases, or terra-cottas, or gems, or coins, he meant them as a sacrifice in honour of gods whom he almost worshipped, hoping they might leads others to worship with him. (1941: 374-375; 2013/I: 405)

Regarding statues Warren left Plato's doctrines about art and professed that sculptures could preserve the completeness of the Greek idea which represented the whole mythological tradition and the essence of areté. Warren filled bronzes and marbles with life by means of associations based on comprehensive knowledge of the past.

Santayana called Warren's Hellenism „obsessive” (Potvin 2011: 86). I think Warren was completely aware of every important philosophical and artistic detail of Greek culture. His collecting work was integral part of his oeuvre, because the body-cult of the Greeks is understandable only in accordance with Antique philosophy. Body-cult and philosophy are not separable in the Greeks' harmonious imaginative system, where religion, poetry, mythology, philosophy and art are expressing the same idea equally. Warren knew this perfectly. The Bostonian collection, his verses and the Defence together depict his life-giving idea. 


\section{III}

"[the photographer] no longer speaks the language of chemistry, but that of poetry. He quotes less Hershel than Pater."

(Fred Holland Day)

"Through the art of the sculptor and the painter the human form acquires
a language, inexhaustible in symbolism, every limb, every feature, every,
attitude, being a word full of significance to those who comprehend." (John Addington Symonds)

Fred Holland Day, the rich American publisher and photographer, radically changed people's vision about male nudes. He had courage, money and time to experiment with the new art, with photography. He is one of the most exciting photographers of the turn of the century and he is the writer of the first valuable articles about photo-aesthetics. At the end of the nineteenth century this new media started to occupy its own place among the arts, but the art criticism of the nineteenth century could not keep up with this new art form.

In his theoretical works, Day analysed the discerning observer, who was able to interpret the details and the unity of a picture. Day privileged imagination over sight and he insisted that "spectators learned the 'indefinite is the read to the infinite' through thoughtful attention to the composition" (Schwain 2008: 97). Sadakichi Hartmann the great critic declared that:

Mr. Fred Holland Day's photographic art is an art full of delicacy, refinement, and subtlety, an art full of deep thought and charm, full of dreamy fascinations; $[\ldots]$ it is not the kind of work to please everybody. It appeals rather to the intellectual and the refined. (Hartmann 1978: 186)

Day believed that photographers could speak the language of poetry. This belief is more important if we know that he admired incredibly the poetry of John Keats. Day didn't use the ancient philosophers's texts directly; he honoured the past through the filtering of the poets and writers of the nineteenth century. $\mathrm{He}$ liked and knew perfectly the ideas of Walter Pater, John Addington Symonds, Edward Carpenter and Oscar Wilde. These authors openly celebrated the male beauty, they wrote about paganism, neoplatonism and Platonic love. For them, Hellenism is the code of a sexual preference, as for the uranist poets and for Day too. In Day's photographs the two main topics are Greek mythology and Christianity. It is impossible to recreate his oeuvre, because his studio burnt down in 1904. But there is a special photo-composition among his remained works, which preserved some of its secrets. In my opinion one of his most exciting pictures is a photocomposition called Beauty Is Truth from 1896. I consider this work of art to be an altar. It is the embodiment of his homage before the inner ideals. Two pictures constitute the composition. The upper photograph called The Genius of Greek Art and the lower is The Entombment. The inscription is a line from John Keats, 
under the upper picture: "BEAUTY IS TRUTH: TRUTH BEAUTY: THAT IS/ ALL YE KNOW ON EARTH AND ALL YE NEED TO KNOW” (Jussim 1981: 110).

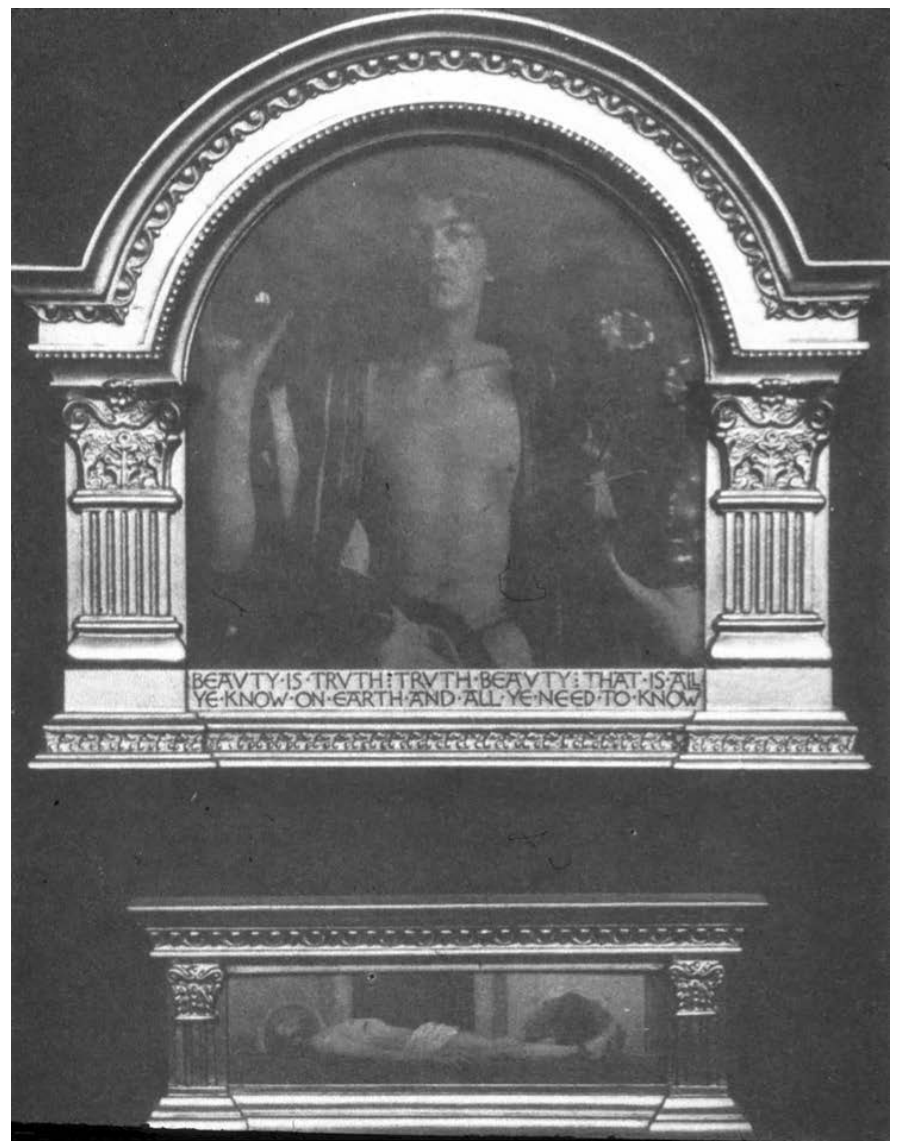

Figure 1. Fred Holland Day: Beauty Is Truth

What can we see in the upper photograph? First of all, there is a boy with a crystal in his right hand, and with poppies in his left. His headband consists of two little wings fastened together, so, we can identify him with Hypnos, who is the god of dreams in the Greek mythology. Ancient literary sources always mention him with poppies. Every little detail is important if we want to understand Day's own world. Some of his friends understood the composition but it was very mysterious to the audience. As Day's contemporary, George Edward Woodberry observed: "It is one of the charms of art that it is not to be completely understood. In an age in which so high a value is put upon facts, information, positive knowledge, it is a relief to have still reserved to us a place apart where it is not necessary to know all" (1914a: 43). Apart from this he concluded that a work of art is "charged with the personality of the artist" (40). So, if we feel sympathy toward Day's pictorial 
world, and we would like to approach his thoughts, we have to analyse the details.

Starting from the title we can find remarkable connections between the essays of John Addington Symonds and the photos of Day. The Genius of Greek Art is a famous study from Symonds from the 1870s. It was a chapter in a book, titled Studies of the Greek Poets. Symonds says: "This chapter was written with the purpose of simply illustrating the aesthetic spirit of the Greeks" (1880: 363). It's a fantastic praise of the Greeks - Symonds tried to find the best way to emulate them. He displayed a vision about the appearance of the Greek Genius as a young boy:

Like a young man newly come from the wrestling-ground, anointed, chapleted, and very calm, the Genius of the Greeks appears before us. Upon his soul there is as yet no burden of the world's pain; the creation that groaneth and travaileth together has touched him with no sense of anguish, nor has he yet felt sin. The pride and the strength of adolescence are his - audacity and endurance, swift passions and exquisite sensibilities, the alternations of sublime repose and boyish noise, grace, pliancy, and stubborness and power, love of all fair things and radiant in the world, the frank enjoyment of the open air, free merriment, and melancholy well beloved. Of these adolescent qualities, of this clear and stainless personality, this conscience whole and pure and reconciled to nature, what survives among us now? (1880: 364)

Symonds felt that the adoration of pure beauty was killed off by Christianity. $\mathrm{He}$ identified the Greek Genius with Achilles, the ideal of the Greeks who preferred and idealized youth rather than manhood. Achilles symbolized the Greek's chivalry to Symonds who declared that:

It will be enough to touch upon the friendship of Achilles for Patroclus as the central point of Hellenic chivalry; [...] comrades, staunch to each other in their love, and elevated by friendship to the pitch of noblest enthusiasm, were among the favourite saints of Greek legendary history. In a word, the chivalry of Hellas found its motive force in friendship rather than in the love of women. (1879: 60-61)

Symonds echoed the same idea as Warren and Day. What Warren shaped in a theory, Day composed into a picture. Symonds remarked that we have to admire the Genius of the Greeks as "we admire a supreme work of art" (59). With this, he called upon his readers to praise Achilles, youth and comradeship, the main features of the Greeks. Through Day's photo, if we value it as an altar, we have the chance to admire it as a work of art about something very essential and important. There is another symbol too, which expresses youth and intellect. The crystal refers to the "clear crystal nature", as a special type of character that appeared in Pater's Diaphaneité (Pater 1900: 220). Pater's words: “A magnificent 
intellectual force is latent within it. It is like the reminiscence of a forgotten culture that once adorned the mind" (218). The crystal-character is heroic, young, clever, deliberate and curious, a real genius. Xenophon used the Greek word $d i-$ aphainein too. He attributed its use to Socrates. It is a state, when the good and valuable attributes shine through the body. Crystallisation and the Genius are related things since the biography of Goethe by G. H. Lewes. In 1863 Lewes wrote in the Life of Goethe about the master that: "He was crystallising slowly; slowly gaining the complete command over himself". Varty exhorts that: "Lewes uses the verb 'to crystallise' to describe the action which the mind of genius performs upon itself as it matures to perfection, turning outward circumstances to its advantage. Pater uses the noun/adjective 'crystal' to denote the already completed product of this process" (Varty 1991). Crystal might be a reference to occultism, which Day was very interested in and he was member in a group called Visionists. Crystal has various meanings.

Symonds emphasized self-control too as a quality needed for perfection. After the model of the Greeks he wanted to cast away total abstinence and mortification and he yearned for self-regulation (1880: 389). Symonds expects, that the old health of the Greeks died with Christianity: "In that age the love of beauty became a tragic disease" (387). This feeling is link to the lower photograph. Thus, the two pictures perhaps symbolise the the two worlds, the Greek, and the Christian, the old and the present. Sin is the most painful burden of this culture, which was completely foreign to the Greeks. Symonds suggested that upon the Genius's soul "there is as yet no burden of the world's pain" (364).

Day had a strong attraction to the Christian cult of suffering. He loved the famous Passion Play of Oberammergau and experimented with displaying Christ's suffering in photographs. He took several pictures of Christ with crown of thorns on his head, and crucified to a huge cross. In every case Day was his own model. Day posed fastened to the crucifix or lay in a grave as in this photo. These pictures might have been the monument of his sufferings because of the suppression of his real, but then, forbidden passions. Day revealed to his friend, Herbert Copeland, "how seriously he admired the concept of suffering as a redemptive experience which brought both maturity and contact with the spiritual world" (Jussim 1981: 50). Yeats and Oscar Wilde had a huge influence on Day's thinking. Day was Wilde's Bostonian publisher and member of his circle of friends. In De Profundis, thinking about religion, Wilde remarks that: "When I think about religion at all, I feel as if I would like to found an order for those who cannot believe; [...] Everything to be true must become a religion" (Wilde 2002: 59). In Beauty Is Truth the impersonated Genius became the hero of a religion based on the adoration of beauty. But for the whole story the dead Christ's figure is indispensable, which calls to mind the importance of suffering. Determined by his Christianity, Day could not forget the existence of sin. Through the Christ figures, he expressed the anguishes of the suffering self, but with the help of Hypnos he left behind suffering in his dreams.

Day joined the two traditions together visually for the audience. In the same work of art, he poeticized the beauty of the naked man to the glory of the Greek 
tradition and exhibited the solitude of the suffering body. When Pater analysed the paintings of Raphael, he emphasized his genius, because he was able to connect the Christian and the pagan traditions. Thus, he valued his work as painted and visible philosophy (Pater 1900: 43). Day shows the same qualities, he could be the Genius of the nineteenth century. He tried to intertwine the motives and symbols of two traditions. However, everything depends on the imagination of the audience. As Woodberry observed:

it is we ourselves who create the image by charging it with our own personality. In this creation we do not simply repeat in ourselves his [the artist's] state of mind and become as it were ghosts of him who is dead; but we originate something new, living and our own. There is no other way for us to appropriate his work, to interpret it and understand it. (1914a: 42)

Day was always too vague for audience. He displayed the unspeakable, but many of his dreams stayed eternally secret.

Santayana, Warren and Day revived something from the Greek tradition to the extent of some gorgeous creation. With the aesthetics of the ecstatic feeling toward beauty they evoked the legacy of Winckelmann and every devoted follower of the Greek idea. Carnal beauty led them to the admiration of the spiritual and the admiration of beauty remained the basis of their thoughts. Their British contemporaries had made a huge influence on them, so the aesthetic Platonism became a living presence in America too in the nineteenth century. Perhaps these writers and artists did not know that their attraction created a new style. Indeed, Santayana's, Day's and Warren's completely shaped life-philosophy gave them a clear and liveable system of ideas, which was more real than their own, modern and changing world. These aesthetically sensitive thinkers re-eroticised the philosophical thoughts about self-creation and the aesthetic way of life. Santayana, Day and Warren did not leave behind only their transient lives, but permanent works with all of their motivations and passions.

\section{References}

Burdett, Osbert and Goddard, E. H. (1941) Edward Perry Warren. The Biography of a Connoisseur. London: Christophers, 22 Berners Street, W. I. In: Warren, Edward Perry (2013) The Collected Works \& Commissioned Biography of Edward Perry Warren. Volume I. ed. with an introduction and notes by Michael Matthew Kaylor. Brno: Masaryk University Press.

Davis, Whitney (2010) Queer Beauty. Sexuality and Aesthetics from Winckelmann to Freud and Beyond. New York: Columbia University Press.

Foucault, Michel (1983) "Self Writing." In: Dits et écrits, Vol. IV., 415-430. Available at http:// foucault.info/documents/foucault.hypomnemata.en.html. Accessed on May 21, 2015.

Foucault, Michel (1990) The History of Sexuality. The Use of Pleasure. New York: Vintage Books. A Division of Random House, Inc. 
Hadot, Pierre (1995) Philosophy as a way of Life. Spiritual Exercises from Socrates to Foucault. Oxford UK and Cambridge USA: Blackwell.

Hall, G. Stanley (1879) "Philosophy in the United States." First published in Mind (4): 89-105. Available at http://psychclassics.yorku.ca/Hall/philosophy.htm/. Accessed on July 2, 2012.

Hartmann, Sadakichi (1978) "F. Holland Day: A Decorative Photographer." In: Lawton Harry W. and George Knox with the collaboration of Wistaria Hartmann Linton (eds.) The Valiant Knights of Dageurre, Selected Critical Essays on Photography and Profiles of Photographic Pioneers by Sadakichi Hartmann. Berkeley - Los Angeles - London: University of California Press, 186190.

Heller Ágnes (1994) Nietzsche és Parsifal. Budapest: Századvég Kiadó.

Jussim, Estelle (1981) Slave to Beauty. The Eccentric Life and Controversial Career of Fred Holland Day, Photographer, Publisher, Aesthete. Boston: David R. Godine, Publisher.

Martin, Robert K. (1998) The Homosexual Tradition in American Poetry. Iowa City: University of Iowa Press.

Nehamas, Alexander (1998) The Art of Living, Socratic Reflections from Plato to Foucault. Oakland: University of California Press.

Nietzsche, Friedrich (1911) Ecce Homo. New York: The Macmillan Company.

Pater, Walter (1900) Miscellaneous Studies, A Series of Essay. London. Macmillan and Co.

Plato Phaedrus. translated by Benjamin Jowett. The Project Gutenberg Etext of Phaedrus. Available at https://ia600502.us.archive.org/4/items/phaedrus01636gut/phdrs10.txt. Accessed on May 7, 2015.

Plato Symposium. translated by Benjamin Jowett. The Project Gutenberg Etext of Symposium. Available at https://ia600504.us.archive.org/6/items/symposium01600gut/sympo10.txt. Accessed on May 7, 2015.

Potvin, John (2011) “Askesis as Aesthetic Home: Edward Perry Warren, Lewes House and the Ideal of Greek Love." Home Cultures 8 (1): 71-90.

Santayana, George (1896) Sonnets and Other Verses. New York: Stone and Kimball.

Santayana, George (1913) "Dr. Fuller, Plotinus, and the Nature of Evil.” The Journal of Philosophy, Psychology and Scientific Methods, October 23, 1913: 589-599.

Santayana, George (1922) Poems. London - Bombay - Sidney: Constable and Company Ltd.

Santayana, George (1927) Interpretations of Poetry and Religion. New York: Charles Scribner's Sons.

Santayana, George (1930) “Love." In: The Life of Reason or the Phase of Human Progress, Reason in Society. New York: Charles Scribner's and Sons.

Santayana, George (1931) "Platonic Love." In: Smith, Logan Pearsall (ed.) Little Essays drawn from the writings of George Santayana. New York: Charles Scribner's Sons, 100-102.

Santayana, George (1940) “Apologia Pro Mente Sua.” In: Schilpp, Paul Arthur (ed.) The Philosophy of George Santayana. Evanston and Chicago: Northwestern University, 495-606.

Santayana, George (1953) My Host the World. New York: Charles Scribner's and Sons.

Santayana, George (1955) The Sense of Beauty, Being the Outline of Aesthetic Theory. New York: Dover Publications, Inc.

Santayana, George, Cory, Daniel (1957) The Idler and His Works. New York: G. Braziller. Available at http://www.questia.com/PM.qst?a=o\&d=54181189/. Accessed on May 13, 2012.

Schwain, Kristin (2008) “Art for Religion's Sake: Fred Holland Day and The Seven Last Words of Christ". In: Signs of Grace - Religion and American Art in the Gilded Age. Ithaca. New York: Cornell University Press, 71-104.

Shusterman, Richard (1997) Practicing Philosophy: Pragmatism and the Philosophical Life. New York: Routledge.

Symonds, John Addington (1879) “Achilles”. In: Studies of the Greek Poets. London: Smith, Elder \& Co., 15 Waterloo Place, 40-71. 
Symonds, John Addington (1880) "The Genius of Greek Art". In: Studies of the Greek Poets II. New York: Harper and Brothers, Publishers Franklin Square, 363-391.

Varty, Ann (1991) "The Crystal Man. A Study of 'Diaphaneité"” In: Brake, Laurel and Ian Small (eds.) Pater in the 1990s. Available at http://classicweb.archive.org/web/20070223045149/www. uncg.edu/eng/elt/pater/chap15.html Accessed on February 2, 2012.

Vlastos, Gregory (1973) Platonic Studies. Princeton: Princeton University Press.

Warren, Edward Perry (2013) The Collected Works \& Commissioned Biography of Edward Perry Warren. Volume I and II. ed. with an introduction and notes by Michael Matthew Kaylor, Brno: Masaryk University Press.

Warren, Edward Perry [Raile, Arthur Lyon] (1928) A Defence of Uranian Love. Vol.1. London: Privately Printed.

Warren, Edward Perry [Raile, Arthur Lyon] (1930) A Defence of Uranian Love. Vol.2. London: Privately Printed.

Wilde, Oscar (2002) De Profundis. Ware: Wordsworth Classics.

Woodberry, Georg Edward (1914b) The Flight and Other Poems. New York: The Macmillan Company.

Woodberry, George Edward (1914a) "Aesthetic Criticism." In: Two Phases of Criticism. Historical and Aesthetic. Boston: Published for the Woodberry Society, The Merrymount Press, 39-70.

NóRA HoRvÁth is a philosopher and assistant professor at the Széchenyi István University Apáczai Faculty (Institute of Humanities and Social Sciences) in Györ, Hungary. She is an art critic and member of the editorial board of a Hungarian journal (Mühely). Her fields of research include: aesthetics of George Santayana; American aesthetics; aesthetic Platonism; aestheticism; the philosophy of Edward Perry Warren; philosophy of the aesthetic way of life; the role of antipathy and sympathy in the philosophy of Jeremy Bentham; pragmatism; and somaesthetics of Richard Shusterman.

Address: Nóra Horváth, Ph.D., Széchenyi István University Apáczai Faculty, Institute of Humanities and Social Sciences, Györ, Liszt Ferenc u. 42, 9022 Hungary. [email: honora@t-online.hu, horvath.nora@sze.hu] 
